\section{Audibility of Members of Parliament}

Experiments are being conducted in the House of Lords, in which the House of Commons sits while the Lower Chamber is being rebuilt after destruction darng the War, to improve the audibility of members. Tomprehension of a speaker's words is low because the first major reflextion, on which reliance is placed by auditors, especially in the rear of a speaker, is scattered by the extensive wooden carving; moreover, the roof is too high to afford any useful reflexions. The acoustic problem is complicated by the premise that any speaker may jump up and address remarks, theoretically to the chair, but often elsewhere. Permission from the authorities has been obtained to install, as an experiment, three hollow tubes acting as hand-rails, one on each side of the House behind the Treasury and Opposition benches, the third in front of the Hansard and some Press reporters just over the Speaker's chair. Each tube is driven by a horn loudspeaker electro-dynamic driving-unit at one end, the other end having an acoustic termination to obviate reflexions. Along the pipe are small holes, so that reproduced sound from the existing system of microphones is emitted just below a member's ear, or in front of a reporter. It is unlikely that a considerable increase in general audibility can be obtained by any means; but the tipe scheme for low-level individual sound augmentation certainly helps the audition of poor speakers, and is of considerable help when the noise-level increases. In particular, the Press are much more certain of getting the remarks of the Speaker. Present trials will indicate whether the pipe system can be extended with advantage, and possibly incorporated in the new Lower Chamber.

\section{Advisers to the Minister of Civil Aviation}

LoRd Nathan, the Minister of Civil Aviation, has appointed the following to be his advisers in science, business and industrial relations: chief scientific adviser, Prof. George Temple ; chief business adviser, Mr. Leslie Gamage; chief adviser on industrial relations, Lord Dukeston. Prof. Temple is professor of mathematics in King's College, London. $\mathrm{He}$ is also a member of the Aeronautical Research Council. He was seconded for specialist duties to the Royal Aircraft Establishment, Farnborough, during the Second World War. Mr. Leslie Gamage is vice-chairman and joint managing director of the General Electric Co., Ltd. For the past four years he has been president of the Institute of Export. $\mathrm{He}$ is a member of the National Civil Aviation Consultative Council, representing the Joint Air Transport Committee of the Association of British Chambers of Commerce, the Federation of British Industries and the London Chamber of Commerce. Lord Dukeston was the general secretary of the National Union of General and Municipal Workers. He represents the Trade Union Congress on the National Civil Aviation Consultative Council. $\mathrm{He}$ was president of this year's Trade Union Congress, and is the British Government member on the United Nations Organisation Commission to set up a Bill of Human Rights.

\section{Royal Society Empire Scientific Conference}

THE preliminary report of the Royal Society Empire Scientific Conference, June-July 1946, which has now been published by the Royal Society, includes the speeches at the opening ceremony with lists of the morning discussions, of the papers prepared for the Conference, of the delegates, etc. The summaries of the discussions given in this report detail the recommendations (see Nature, July 27, 1946 , p. 136), many of which were afterwards endorsed by the Official Conference. The morning discussions surveyed first some outstanding problems in agricultural science in the Empire, including scientific needs concerned with the soil, the plant and the farm animal. Next some outstanding problems in medical science were discussed, including the physiological and psychological factors affecting human life wader tropical conditions and in industry, and the etiology and control of infectious and transmissible diseases, particularly those which are insect-borne. The present state of the science of nutrition was discussed with particular reference to the special problems of the Empire, including the nutritional status of the indigenous peoples of the Colonies. Improvement of that status was recognized by the Conference as a part of general social and economic policy in the territories concerned, and the Conference strongly urged the need for integrating the efforts of producer, consumer, technical and administrative personnel in effecting improvements in nutrition.

Other discussions covered a variety of topics: modern methods of mapping and exploration by air, including the use of radio technique in ordnance survey with special reference to particular parts of the Empire; scientific information services and methods of improving the interchange of scientific workers throughout the Empire, including the future of the scientific liaison offices that were established during the War ; Empire co-operation in the scientific field with existing and projected international organisations; physical standards of measurement, the collection of scientific records and material and risks involved in the distribution of plants, seeds and animals, and so on. A general statement on land utilization and soil conservation emphasizes the importance of erosion surveys, soil surveys, and investigations relating to the maintenance and improvement of soil fertility, and urges the importance of surveys to determine the present pattern of and trends in land use, as a basis for the maintenance of soil fertility, bearing in mind the conflict between agricultural and other interests. A discussion on the need for a co-ordinated survey of the mineral resources of the Empire led to a general statement urging the compilation of reliable data on mineral resources. Discussions on the natural products of the Empire and the chemical industries that are, or might be, based on them and on the post-war needs of fundamental research, the latter of which revealed a particular shortage in the Commonwealth of scientific workers in such fields as taxonomy, genetics and microbiology, completed the proceedings.

\section{Textile Industry and the University of Leeds}

The report to the Clothworkers' Company of the Advisory Committee on the Departments of Textile Industries and Colour Chemistry and Dyeing, University of Leeds, 1945-46, pays a high tribute to the work of the late Prof. F. M. Rowe. No appointment has yet been made to the research fellowships in dyeing or in physical chemistry; but research workers of the Sisal Growers' Association have continued to be accommodated in the Dyeing Depart. ment. Dr. E. Race, in collaboration with Prof. Rowe and Prof. J. B. Speaknaan, established a new 
technique for examining the constitution of the dye-chromium complexes obtained when wool is dyed with chrome mordant dyes, and with Dr. C. B. Stevens commenced work on the kinetics of chromium dye complex formation, including a study of the rates of formation and heats of combustion of chromium complexes of a series of dyes. Dr. E. M. Hunt and Prof. F. M. Rowe completed an investigation to establish degradation processes for determining the constitution of indigoid, thioindigoid and related types of vat dyes in substance, and $\mathrm{Mr}$. F. M. Smith commenced a similar investigation of triphenylmethane dyes. Derivatives of catechol have been prepared for examination as intermediates for dyes, and Dr. A. T. Peters has completed an investigation of derivatives of $3: 4$-di-tert.-butylacenaphthene and derived indigoid dyes, and with Dr. R. J. Moualim commenced the preparation and orientation of a series of derivatives of 2-tert.-butylnaphthalene. Although the entry of British students was seriously affected by the demands of national service, the total number was fully maintained by ex-Service students and students from abroad, and the number of students in the Department of Textile Industries caused serious overcrowding.

The report of the latter Department refers to Prof. W. T. Astbury's election to the newly instituted chair of biomolecular structure, and when his work is transferred to new quarters, the Textile Physics Laboratories will be supervised by Mr. H. J. Woods, who has now been appointed lecturer in textile physics. A new scheme of work on textile finishing has been undertaken by Dr. C. S. Whewell in conjunction with Mr. C. R. Ricketts, and work on wool, rayon, jute and sisal has continued. Messrs. Courtaulds, Ltd., have now made a grant of $£ 60,000$ for building and equipping a Division of Rayon Technology within the Department. Lists of publications are included in the report.

\section{Mosquitoes and Yellow Fever in the Sudan}

DR. J. LewIs, of the Stack Medical Research Laboratories, has discussed the relationship of mosquitoes and yellow fever in the Sudan (Bull. Ent. Res., 3, pt. 4 ; 1947). It appears that most of the southern half of the Sudan is a yellow fever area in the sense that people immune to the disease have been found in many parts of that territory. The chance of the disease spreading to parts hitherto free is liable to be increased by such outbreaks as the great Nuba Mountains epidemic of 1941. It is noteworthy that several towns in the Sudan lie on import. ant air, rail and water routes leading to countries free from yellow fever. Some 140 species of mosquitoes are known from the Sudan, and, of these, twelve kinds are known to be capable of transmitting the yellow fever virus, while several other kinds are suspected in this connexion. Two further species are able to retain this virus throughout life without apparently possessing the ability to transmit the disease by their blood-sucking habits. The object of the present paper is to record information on the occurrence and distribution of mosquitoes in the Sudan. The Anophelines are only briefly considered because they are unlikely to transmit yellow fever. Among the Culicines that affect man and frequent human habitations, Aedes taylori is believed to be one of the chief vectors in the case of the Nuba Mountains epidemic. As regards Aedes cegypti, it appears that mosquito control measures have had the effect of rendering urban yellow fever epidemics, carried by this species, virtually impossible, and the disease has been exterminated from Khartoum. The relation of Taniorhynchus africanus to the disease is of special interest owing to its wide range and abundance in the Sudan. While there is no evidence that this species can act as a vector, it seems likely that it can act in this way in limited epidemics about the Upper Nile area. The author concludes by discussing the measures of mosquito control in the Sudan, which greatly restrict the possibilities of the spread of yellow fever. At the same time it is evident that the control of a rural epidemic would be difficult to achieve.

\section{University of London Appointments}

THE following appointments have been announced by the University of London: Mr. E. H. Phelps Brown, University lecturer in economics at Oxford, to the University chair of economics of labour tenable at the London School of Economics as from October 1 ; Dr. Harold Burton, senior lecturer in organic chemistry at the University of Leeds, to the University chair of chemistry tenable at King's College of Household and Social Science as from October 1; $\mathrm{Mr}$. P. T. Bauer, lecturer in economics at the London School of Economics and Political Science, to the University readership in agricultural economics tenable at the School, as from October 1; Mr. R. H. Coase, lecturer in economics at the London School of Economics and Political Science since 1938, to the University readership in economics tenable at the School as from October 1 ; Dr. P. C. C. Garnham, senior parasitologist in charge of the Division of Insect-borne Diseases in the East African Medical Service, to the University readership in medical parasitology tenable at the London School of Hygiene and Tropical Medicine; Mr. J. W. H. King, senior lecturer in civil engineering at University College, Nottingham, to the University readership in civil engineering tenable at Queen Mary College as from October 1. Dr. M. M. Loève, lecturer at Birkbeck College, to the University readership in applied mathematics tenable at Birkbeck College as from October 1; Dr. F. T. G. Prunty, lecturer in chemical pathology at St. Thomas's Hospital Medical School, to the University readership in chemical pathology tenable at the School as from October 1; Dr. Richard Rado, lecturer in mathematics in the University of Sheffield, to the University readership in pure mathematics tenable at King's College as from October 1 ; Dr. F. R. Selbie, assistant pathologist at the Bland-Sutton Institute of Pathology, to the University readership in bacteriology tenable at Middlesex Hospital Medical School as from October 1 .

The titì of professor of zoology in the University has been conferred on Dr. Alastair Graham, in respect of the post held by him at Birkbeck College; the title of professor of zoology in the University has been conferred on Dr. A. J. Grove, in respect of the post held by him at Queen Mary College; the title of reader in pure mathematics in the University has been conferred on Dr. R. G. Cooke, in respect of the post held by him at Birkbeck College; the title of reader in civil engineering in the University has been conferred on Dr. S. R. Sparkes, in respect of the post held by him at the Imperial College of Science and Technology.

The degree of doctor of science has been conferred on Prof. E. J. King, professor of pathological chemistry at the Postgraduate Medical School. 